GYENES FRUZSINA

\title{
A Wifi-falu programról
}

Interjú Maradi Istvánnal, a Magyar Telekom műszaki vezérigazgató-helyettesével

0

$\mathbf{R}$

$\mathbf{M}$

Á

C

I

Ó

$\mathbf{S}$

$\mathbf{T}$

Á

$\mathbf{R}$

S

$\mathbf{A}$

D

Így hivatkozzon erre a cikkre:

Gyenes Fruzsina. „A Wifi-falu programról”.

Információs Társadalom VIII, 4. szám (2008): 140-141.

= https://dx.doi.org/10.22503/inftars.VIII.2008.4.17

A folyóiratban közölt müvek

a Creative Commons Nevezd meg! - Ne add el! - Így add tovább! 4.0

Nemzetközi Licenc feltételeinek megfelelöen használhatók. 
Gyenes Fruzsina

\section{A wifi-falu programról \\ Interjú Maradi Istvánnal, a Magyar Telekom müszaki vezérigazgató-helyettesével}

\section{Gy. F.: Miért támogatta a Magyar Telekom a wifi-falu programot?}

M. I.: Ez a kezdeményezés, vagyis hogy a széles sávú internet eljusson a hátrányos helyzetú vidékeken élố családokhoz is, összhangban van a vállalat elképzeléseivel. Szeretnénk ezekre a területekre is elvinni a Telekom internetszolgáltatását, de ez nem mindig könnyú. Érthetô, hogy fölkarolásra érdemesnek gondoltuk a wifi-falu ügyét. Megtetszett a program szelleme és a szervező, az Internet Terjesztéséért Alapítvány lelkesedése is. Olyan technológiát alkalmazunk, amelynek kezelésében otthonosan mozog a Magyar Telekom: mi elvisszük az adott településre a vezetékes technológiát, és onnantól wifi-vel biztosítják a széles sávú internetszolgáltatást.

\section{Gy. F.: Milyen támogatást nyújtott a cég a program megvalósitásához?}

M. I.: A Magyar Telekom a saját eszközeivel és technológiájával egy kifejezetten erre a célra létrehozott, speciális megoldást dolgozott ki azokban a falvakban, amelyeket az alapítvány megnevezett, a kapcsolat végpontjához pedig az alapítvány szereltette fel a vezeték nélküli kommunikációhoz szükséges berendezéseket. A konstrukciót az alapítványon keresztül 2009 végéig az érintett, igen szerény körülmények között élő fogyasztóknak adományozzuk.

Gy. F.: Az egyeztetések során milyen technológiai, jogi, iisleti és egyéb problémák meriiltek fel? M. I.: Az egyik legfontosabb feladat megszerezni az épülettulajdonosok beleegyezését ott, ahol a WiFi-antennát szeretnénk elhelyezni. Ez nem is olyan egyszerú például egy bolt, egy templomtorony vagy egy községháza esetében. Az engedélyek megszerzésében sokat segített az alapítvány. Emellett adódott egy sor múszaki természetû feladat is, például kábelfektetés, villámvédelem, folyamatos áramellátás, de ezeket megoldottuk. És persze sok nehézséget okozott az állandó versenyfutás az idốvel.

\section{Gy. F.: Hogyan illeszkedik ez a program a Magyar Telekom támogatási rendszerébe?}

M. I.: A Magyar Telekom Magyarországon az elsók között csatlakozott az Európai Uniónak az e-befogadást ösztönzó kezdeményezéséhez, melynek célja a hátrányos helyzetú csoportokhoz tartozó állampolgárok, köztük az idősek, a fogyatékosok és a romák segítése és integrálása a hátrányaik leküzdésében való szerepvállalással. Emellett elkötelezettek vagyunk az információs társadalom szélesítése, a digitális szakadék csökkentése, az információs társadalom előnyeinek, hasznainak népszerúsítése mellett. A Magyar Telekom - amellett, hogy a digitális írástudás elterjesztéséért tevékenykedik - több célzott projektben is részt vesz, amelyek az e-befogadást segítik. Ebbe a tevékenységbe illeszkedik a wifi-falvak alapítványon keresztül való 
támogatása is. A mi segítségünk mindig akkor a leghatékonyabb, ha a saját termékünk, szolgáltatásunk révén nyújthatunk támogatást. A wifi-falu esetében ez teljes mértékben megvalósul.

\section{Gy. F.: Piacépitésnek is tekinti a cég ezt a programot?}

M. I.: Ez a program távol áll a direkt profitszerzés lehetôségétól. A WiFi-s internetet hátrányos helyzetû családok fogják használni, és róluk aligha a nyereség és a piac jut eszünkbe. A Telekom abban lát fantáziát, hogy a program támogatásával tágítani tudja a digitális kultúrával megbarátkozók körét. Azok a gyerekek, akik most számítógéphez, internethez jutnak, késóbb természetes módon fognak használatba venni egy sor világhálós szolgáltatást. Ilyen lesz például az e-ügyintézés és még számtalan más szolgáltatás is, amelyeknek a hátterét a távközlés adja. Ezzel a programmal azt az elvet támogattuk, hogy mindenkinek esélye legyen eljutni a digitális világhoz. Ha ma egy nehezebb sorsú család gyermeke nem fér hozzá ezekhez a lehetôségekhez, csökkennek az esélyei a munkaerôpiacon.

Gy. F.: Vajon azok közül, akik most internethez jutnak, a támogatási szerzódés lejárta után hányan fogják továbbra is használni?

M. I.: Nem lehet tudni, hogyan alakul a számuk, amikor majd fizetni kell a szolgáltatásért. De a tapasztalat szerint az, aki belekóstol az internetbe, nehezen szakad el tóle. Persze lesz, aki az ingyenes szakasz után lemond róla, de a többség életébe véglegesen be fog költözni. A felmérések azt mutatják, hogy a háztartásokból nem azért hiányzik az internet, mert az emberek elleneznék, hanem mert még ki sem próbálták. De ha túllépve az elsố akadályon megismerkednek vele, olyanná válik számukra, mint a vezetékes víz vagy a villany, és az erre fordítandó összeget félre fogják tenni.

\section{Gy. F.: Hogyan formálódhat a wifi-falu múködési modellje 2009 után?}

M. I.: Ha az alapítvány ügyszeretete és a Telekommal való jó viszonya megmarad, akkor szívesen folytatjuk a támogatást. Mi adjuk a múszaki tudást, s ehhez a lelkesedést és a lendületet a partnernek kell hozzátennie. A puszta technológia mit sem ér a lélek nélkül. Ezt éppen az eddigi együttmúködésünk bizonyította. Láttam a fényképeken, ahogyan az alapítvány munkatársai nehéz sorsú embereket tanítottak az internet használatára. 